\title{
Heroes, Mates and Family How Tragedy Teaches Us About Being Australian
}

\author{
SARAH GILLMAN
}

During the Howard Government's term in office, from March 1996 until November 2007, there were a number of significant tragic events involving Australians, both domestically and overseas. These included the Port Arthur shootings (1996), the Thredbo landslide (1997), September 11 (2001), the Bali bombings (2002, 2005), the Boxing Day tsunami (2004), the London bombings (2005) and the Beaconsfield mine collapse and rescue (2006). Changes to news production and culture during this same period made disaster and tragedy big news. Victims were elevated to celebrity status and the media provided live, saturation coverage of events as they unfolded. The tabloidisation of news with its focus on the domestic and private lives of news-makers coincided with the growth of news as an entertainment and commercial product. Media consumers had access to more news than ever before. And in a period in which there was increased global insecurity, the media provided both a context for witnessing, and deconstructing, tragedy and disaster and a platform for political leaders to set the tone of public debate. Consequently, John Howard, as the prime minister, was positioned at the centre of the media-sphere when disaster happened. Journalists and camera crews waited on doorsteps, sat in halls and churches and attended to their pigeonholes in the parliamentary press gallery to find out what John Howard had to say about respective events. They listened to him being interviewed on talkback radio and on current affairs 
television: they followed him to rallies and memorials and relayed his words to the Australian public. This intense media focus enhanced the role of the then prime minister as the 'principal national opinion leader and mobiliser'. ${ }^{1}$

Coverage of 'media events' such as disasters disrupt the normal flow of news, particularly in broadcast media. Regular programs are suspended as media outlets cross 'live' to the scene of the tragedy. Print media with access to audiences via web-pages update news as it breaks. Framing of the story across all outlets tends to be homogenous. Reporting is respectful and reverential. Eyewitnesses are found to tell the audience what happened and 'experts' quickly organised to explain the event and give it context. These 'experts' include political leaders. Failure to provide comment can be politically damaging, as former Opposition leader Mark Latham discovered when he delayed publicly reacting to the 2004 Boxing Day tsunami and was widely criticised despite later releasing a statement that revealed he had suffered from pancreatitis. At the same time, dissenting or 'deviant' voices are sidelined, as boxer Anthony Mundine discovered when he claimed that America was partially to blame for the attack on the World Trade Center on 11 September $2001 .^{2}$

In the immediate, spontaneous coverage of disasters, the media operates within what Hallin calls the sphere of consensus. ${ }^{3}$ Opinions are sought which promote reconciliation in an attempt to restore order and even though the media itself advocates for consensus, the coverage appears objective because of the very fact that it falls within the consensus sphere. Commentators such as the prime minister who speak from the centre of the sphere have the highest credibility; those who speak from outside the sphere have less.

Crossing 'live' to John Howard during 'media events' that occurred when he was prime minister provided him with a platform to convey essentially unedited, unmediated messages to audiences who were trying to make sense of what happened. An analysis of Howard's reactions and public statements to disaster and tragedy over his time in office shows he used the platform to emphasise the concepts of family, mates and heroes, or what he described as the 'basics of life'. ${ }^{4}$ It shows that he used and defined these terms to portray them as key fundamentals of 'Australianess', entwining them and linking them to meta-narratives of national identity to construct a framework that helped him direct the news agenda and influence the public debate about Australian values. In doing so, his references to 
family, mates and heroes, and national identity at times of crisis teleologically propelled Australian society through more than a decade of marked social and political change.

John Howard was widely known to ad lib, to speak off the cuff and from dot points and, unlike his predecessors such as Paul Keating, he minimised reliance on professionally written speeches. In her article, 'In the Beginning was the Word', journalist Margaret Simons wrote that 'John Howard's office says nobody writes his speeches for him. He talks to his advisers to gather facts but either speaks without a script or writes his speeches himself.' 5 It is something that the former prime minister regarded as a positive trait. In an interview with political correspondent Michelle Grattan he said, 'I don't have to devote these huge chunks of time to going through speeches that people have prepared for me'.6 This approach, practically and strategically, helped to convey the impression that Howard's reactions during 'media events' were spontaneous and personal.

John Winston Howard took office as Prime Minister of Australia on 11 March 1996, after winning a landslide election against a Labor Party led by Paul Keating. Forty-eight days later, Martin Bryant shot dead thirty-five people at Port Arthur, in Tasmania. It was, as the new prime minster said, a shocking and tragic event. Parliament was convened and in a speech to the House of Representatives, the Prime Minister sought to have members extend their deepest sympathy to the families and friends of those killed and injured and the Speaker convey this resolution and sincere wishes to those families affected by the enormous tragedy:

There can be few things in life more innocent than a pleasant Sunday afternoon in a remote, isolated area of this country. To think that violence of this magnitude could be visited upon such innocent behaviour and in so many instances on people who were living in the older and twilight periods of their lives is something quite shocking in its dimension. ${ }^{7}$

At a news conference the day after the shooting, Howard announced his intention to tighten gun laws to prevent Australia going 'willy-nilly down the American path of gun use and violence'.8 This was not, he said, something that belonged in Australian culture. It was during the gun-control campaign that John Howard got to know pharmacist Walter Mikac, who had lost his wife and two daughters at Port Arthur. Mikac became the human face of the gun debate and Howard was subsequently 
involved in the formation of the Alannah and Madeleine Foundation, established in memory of the two young Mikac girls. John Howard described Walter Mikac's loss as a metaphor for the shootings and symbolic of the attack on ordinary Australians enjoying family life. He wrote the forward to Mikac's book To Have and To Hold, pointing to the importance of family in Australian society:

The family is our society's moral and social anchor, providing us with strength and hope. Those who might be tempted to take for granted the comfort and joy provided by our families cannot help but reflect upon what is truly important in our lives as a result of Port Arthur. ${ }^{9}$

This focus on family as a core Australian value reflected Howard's own strong family ties. Photos of his own children and his wife, Janette, were featured on his ministerial website and when he first came to office he refused to relocate to Canberra on the basis that his children were finishing school in Sydney and his wife had close friends and family there. Indeed, Howard didn't move out of his own childhood home until he was in his thirties, living with his mother who had raised him and his brothers alone after his father died when Howard was a teenager. In the 1950s, a young John Howard appeared on the Have a Go radio quiz. Archival audio reveals him telling the host Jack Davey that he has come with his brother and sisterin-law, who are in the audience, with the aim of winning his mother a washing machine to make her life easier. (He eventually leaves with 100 bars of soap.) ${ }^{10}$ Howard is in demographic terms a traditionalist, and his attitude to family is symptomatic of growing up in the postwar Menzies years. It was, as Geoffrey Bolton notes, a period of modernity and familism, when 'material security for home and family was accepted in mainstream political debate as the great goal of Australian society'.11 It was a time when family provided the basis of social organisation for many Australians, revolving as it did around both the immediate household and wider kinship, and encouraging upward social mobility.

Family was one of Howard's driving fundamentals and it formed a key part of his public reaction to disaster and tragedy. In the speeches and interviews he gave in response to the loss of lives in the September 11, Bali and London bombings he extended his sympathy to the families who lost members. He spoke of parents who watched their children leave home to travel and see the world as young Australians had always done. He referred to the loss of fathers and mothers, and brothers and 
sisters, and increasingly set this loss against a backdrop of people enjoying what he described as the simple pleasures of Australian life. In response to the 2002 Bali bombings, for example, he told Parliament that it would 'be counted as a day on which evil struck with indiscriminate and indescribable savagery, young Australians who were engaging in an understandable period of relaxation'.12

Many of us will feel a poignancy of this attack coinciding with the end of the football season in Australia. So many of the young people in that club that night were members of Australian rules teams, rugby league teams and rugby union teams. They were having a bit of fun at the end of a hard season. ${ }^{13}$

At a commemorative service the following year in Bali Howard told journalists he was moved to tears when he met families of victims of the bombings. Photos and television footage show him making an impromptu visit to Kuta Beach to join a surfers memorial service, 'walking barefoot in slacks and an open necked shirt with a sprig of wattle pinned to his pocket, speaking with members of the crowd'.14

John Howard also referred to this loss of family in most of the public responses he made during the Beaconsfield Mine Rescue in April and May 2006. When news came through that miner Larry Knight had been found dead, Howard told the media the weight of the loss on his family must be unbearable. A public reception at Parliament House in Canberra was held for rescued miners Brant Webb and Todd Russell, their families and others involved in the rescue, and in his speech Howard told the audience that he was struck by the two miners' remarks about their families, about playing football with their children and writing messages to them on their arms. He concluded, 'in the simple words I think those two men resonated with the parents, and in particular the fathers of Australia, in a way that I don't think two men have ever quite been able to do'.15

John Howard is a fourth-generation Australian of Anglo-Celtic ancestry. His grandfather and father fought in World War I. His family ran a small business in suburban Sydney where a teenage Howard worked. As noted, his father died when Howard was in his teens. Various biographical notes show that Howard was keen on football, cricket and debating at school and was a member of the Air Training Corps at Canterbury Boys High School during the 1950s. He won a scholarship to Sydney 
University to study law and later became a solicitor before entering Federal Parliament as the member for Bennelong in 1974. He is married with three children.

Howard's repeated references to family at times of crisis and his emphasis on specific features such as sport and hard work revealed how deeply his ideology and discourse about what it was to be Australian were anchored in his own biography. His own experiences of growing up in Australia and being an Australian were echoed in his reactions to disasters and tragedies, and were conveyed to viewers, listeners and readers during homogenous and consensual coverage of 'media events'. Via a process of interpellation, Howard hailed an 'Australian' audience which mirrored himself, from a stage where there were few if any dissenting voices to challenge the reflection. Interestingly, he did not refer to specific historical or contemporary heroic individuals who could be held up as role models to evoke national sentiment; instead, his discourse was dominated by references to 'ordinary' Australians. As Duncan S. A. Bell states:

questions of personal and collective identity are fundamental in any attempt to grasp the dynamics of nationalism. To recognise oneself as a member of a particular nation-indeed to feel a powerful sense of belonging - and to be recognised by others as such, is a perquisite for the formation of the inside/outside, self/other, us/them boundaries that define the topography of nationalist sentiment and rhetoric. 16

John Howard's use, as prime minister, of collective nouns (fathers, parents, young people, sons, daughters, sisters, brothers) drew his audience into the text through a process of identification. His repeated references to sport, celebrations and fun after hard seasons and hard work, pleasant Sunday afternoons in twilight years, parents sending their children off into the world and so on worked to construct a picture of an innocent Australia into which evil and indiscriminate savagery trespassed, threatening a purer way of life. This evil could be both personified and abstract, but it underpinned a divide between 'us' as Australians reflected in John Howard's image and 'them' who were not. Over the Howard decade the term 'un-Australian' was attached to anyone who was not 'us' and who tried to debate the values of John Howard's Australia. The analysis of his public reaction to disaster and tragedy shows that he evoked these 'values', which include fairness, egalitarianism, honesty and hard-work, defining them as common sense and self-evident. His message was 
reinforced by the nature of his delivery (apparently spontaneous and spoken in plain English) and by the media's framing (homogenous, reverential and without contest). Of the Beaconsfield mine rescue, for example, he said:

We saw guts, we saw resilience, we saw courage, we saw strength and we saw enormous endurance ... everything that is good about the Australia we love and the Australia we want to preserve and the Australia we want to make better because these dramatic events remind us of the basics of life. ${ }^{17}$

During rescue efforts, members of the Australian family were called on to work together as mates, where, according to Howard, they defined themselves as heroes: ordinary Australians going about their daily lives who were called to assist in times of crisis and respond with courage and professionalism, working together with differences of occupation and background, religion and political background put aside. As he said of the Thredbo landslide rescue workers, they worked together 'as friends, mates and comrades under great adversity hoping to assist Australians in desperate circumstances'.18

I believe Australia's emergency services are the best in the world ... and those marvellous orange uniforms are now becoming part and parcel of the Australian psyche. They are part of Australian folklore. You see them everywhere whether it's fires, the Thredbo disaster ... wherever it may be. ${ }^{19}$

This articulation of 'mates' and 'heroes' reinforced hegemonic discourses of Australian identity through the identification and promotion of virtues such as bravery and sacrifice as intrinsic national characteristics. It reflected Howard's own understanding of these traits because they were applied (and with media assistance shown to apply) to predominantly white men whose uniforms disguised their respective backgrounds and transformed them from individuals into the anonymous group or team as they went about performing potentially dangerous physical work. This discourse provided Howard with an enduring rhetorical link to historical events such as Anzac Day, which he used to shape particular narratives of what it was to be 'Australian'.

Over the period of the Howard Government these narratives were reinforced in acts of commemoration and acts of public mourning, such as those held for the 
victims of Port Arthur, the Bali and London bombings and the 2004 tsunami. Private and individual experiences thus became collective experiences as the unifying rituals were made available to much wider audiences via media coverage. Just as a family comes together at a funeral, so the Australian family was seen to be united in a shared moment of grieving; 'media events' emerged from earlier 'media events' and once again the framing contributed to consensual social cognition. Features of the media coverage often included the national anthem and the Australian flag, which visually reinforced Howard's statements as he was shown, patriarch-like, with other mourners. Close-up media shots of grieving people, including Howard and his wife, blurred the boundary between public and private. Audiences were invited to become part of narratives that tapped into the commonly perpetuated myths of who we were and what we valued as a nation. According to Barthes, such myths are conveyed to an audience via the systematic organisation of signifiers around a set of connotations or meanings. John Howard's Australian audience decoded these myths within its own culturally learned understanding to construct a form of 'Australian' nationalism which was reflected back to them in what they were watching or reading. According to journalist Misha Schubert, Howard's success in touching the right note at these times lay in restraint:

People want their leaders to speak to them and for them, in difficult times.

But we're still wary of politicians making mileage of such events ... his speech at the memorial service in Parliament's Great Hall after the Bali Bombing was ... magnificant. Unscripted, simple, powerful. ${ }^{20}$

In his book The Power of Speech: Australian Prime Ministers Defining the National Image, James Curran notes the articulation of Australian identity through ideas and language is not haphazard or ad hoc but 'an attempt to use a language that leaders feel best helps them connect to the hearts and minds of the people they seek to represent'.21 As mentioned earlier, Howard eschewed speech writers to position himself as speaking authentically to middle Australia, or 'ordinary' Australians or battlers like himself, and offering practical, no nonsense reactions to disaster and tragedy. But as Catherine Lumby noted at the time, while 'some of our most powerful conservative politicians including the prime minister have moved onto plain English, they are using it as a Trojan horse, as a device for manipulating and dividing public debate'.22 
The hallmark of this political 'plain speaking' is a claim to be speaking common sense. The act of communicating (and, implicitly, running a country) is framed as a simple and transparent process where there's no room for disagreement about what key terms like 'Australian' or 'normal' might mean. 23

Lumby adds that anyone who tries to challenge these terms is marginalised and labelled as being 'out of touch with the real world'. ${ }^{24}$ John Howard's use of plainly spoken references in times of crisis to family, mates and heroes helped construct an Australian identity which he described as common sense and without debate. His approach was aided by the media framing of his reactions. Consequently, anyone who tried 'to unnecessarily complicate the obvious [such] as intellectuals, elites, or special interest groups' 25 was seen to speak from outside the sphere of consensus and to lack credibility. This allowed John Howard to construct a contemporary Australian national identity and, as Nairn asserts, nations that share a sense of nationalism can push forward toward a common goal.26

During the Howard Government's term in office, Australia underwent quite radical economic, political, social and cultural change. As David McKnight told the Sydney Institute in a speech marking ten years of the Howard Government, it was a decade during which the government sought to address all kinds of economic and social issues through a combination of individualism, competition and free markets. ${ }^{27}$ It was a period, as Brian Loughnane, the federal director of the Liberal Party, told the Hudson Institute in Washington, marked by an extensive and critical shift in social policy and labour reform. 28

Family, mates and heroes may seem like commonsense, plain-English terms, but how they are understood, how they are used and who they are applied to is at the heart of understanding how John Howard controlled the debate about Australian values and national identity and how he used them to propel the country through a decade of social, political and economic change. While the terms family, mates and heroes, as defined by Howard, applied, for example, to the victims of disaster and tragedy, to their families and friends and the individuals and groups who were involved in operations such as rescues and commemoration services, they were not applicable to other situations. They could not, for example, be ascribed to young men from the western suburbs of Sydney who went to help brothers and friends on 
the beaches of the Sutherland Shire during the 2005 Cronulla riots, or to migrants who arrived illegally and were sent with their young children to detention centres, or to provocative religious leaders who looked outside Australia for inspiration. Citizens of John Howard's Australia knew what he meant by the terms family, mates and heroes and, as Nick Dyrenfurth observes, how Australians, and particularly the nation's leaders, have 'imagined' and 'argued' the citizen has framed the boundaries of citizenship.29 It ultimately produced the difference between Australians and those who were Un-Australian, between those who were included and those who were not.

Sarah Gillman is a PhD Candidate in the School of Communication at the University of South Australia. Her thesis explores the impact of celebrity on news coverage of traumatic events. Her previous published work researched talkback radio, and changes to news values and reporting. She is currently working in mainstream media after teaching in tertiary media and journalism programs. <gilsj006@students.unisa.edu.au>

\footnotetext{
-NOTES

${ }^{1}$ In his book The Power of Speech: Australian Prime Ministers Defining the National Image, Melbourne University Press, Melbourne, 2004, author James Curran cites Clem Lloyd from his article 'Prime Ministers and the Media' in Patrick Weller's book Menzies to Keating: The Development of the Australian Prime Ministership, Melbourne University Press, Melbourne, 1992. In the article, Lloyd in turn acknowledges the work of Colin Seymour-Ure in his book The British Press and Broadcasting since 1945, Basil Blackwell, Oxford, 1991.

2 In the immediate wake of September 11, boxer and footballer Anthony Mundine told journalists that American foreign policy had helped foster terrorism. His comments were reported and he found himself subject to quite savage criticism in the media from commentators, talkback callers, letter writers and contributors to online blogs.

3 Daniel Hallin, The 'Uncensored War': The Media and Vietnam, Oxford University Press, Berkeley, 1986. ${ }^{4}$ John Howard's reaction to the noted disasters and tragedies were originally made publicly available on his prime ministerial webpage. Following his party's defeat in the 2007 federal election and his own loss of office, the webpage has been archived by the National Library of Australia, $<$ http://nla.gov.au/nla.arc-10052>. Archival media reports supplement the analysis.

${ }^{5}$ Margaret Simons, 'In the Beginning was the Word', Age, 15 March 2003.

6 Michelle Grattan, 'Home-Grown PM', Australian Financial Review Magazine, 25 October 1996.

${ }^{7}$ John Howard's Speech to the House of Representatives, 30 April 1996, Hansard, p. 23.

8 John Howard's Ministerial Statement to the House of Representatives, 6 May 1996, Hansard, p. 390.
} 
9 John Howard in Walter Mikac and Lindsay Simpson's book, To Have and To Hold: A Modern Day Love Story Cut Short, Pan Macmillan, Sydney, 1998.

10 Archival material of this radio appearance is held at the National Film and Sound Archives

11 Geoffrey Bolton The Middle Way: The Oxford History of Australia, vol. 5, 1942-1988, Oxford University Press, Melbourne, 1990.

12 <http://www.hansard.aph.gov.au/hansard/reps/dailys/dr141002.pdf>.

13 <http://www.hansard.aph.gov.au/hansard/reps/dailys/dr141002.pdf>.

14 Mark Baker, Age, 13 October, 2003, p. 9.

15 Address to reception for the Beaconsfield community at Parliament House, 29 May 2006,

$<$ http://pandora.nla.gov.au/pan/10052/20060621-

0000/www.pm.gov.au/news/speeches/speech1956.html>.

16 Duncan S. A. Bell 'Mythscapes: Memory, Mythology, and National Identity', British Journal of

Sociology, vol. 54, no. 1, March 2003, pp. 63-81.

$17<$ http://pandora.nla.gov.au/pan/10052/20060621-

0000/www.pm.gov.au/news/speeches/speech1956.html>.

18 <http://www.aph.gov.au/hansard/reps/dailys/dr250897.pdf>.

19 Doorstop media, Wollongong, August 24, 1998.

<http://parlinfo.aph.gov.au/parlInfo/search/display/display.w3p;adv=;db=;group=;holdingType=;id=; orderBy=date-

eLast;page=0;query=john\%20howard\%20emergency\%20services\%201998\%20SearchCategory_Phra se $\% 3 \mathrm{~A} \% 22$ media\%22;querytype=;rec=13;resCount=Default $>$.

20 Misha Schubert, 'PM's Arms Not All-embracing', Age, 16 January 2005.

21 Curran, p. 20.

22 Catherine Lumby, 'Political Speak: Double Talk vs. Plain English', Sydney Writers' Festival 2005, $<$ http://www.plainenglishfoundation.com/documents/Lumbyspeech_002.pdf>.

${ }^{23}$ Lumby, p. 2.

24 Lumby, p. 2.

25 Lumby, p. 2.

26 Tom Nairn, The Break-up of Britain: Crisis and Neo-nationalism, New Left Books, London 1977.

27 David McKnight, 'Modern Australia: The Ascendancy of the Right in Modern Australia', The Sydney

Papers, vol. 18, no. 1, Summer 2006.

${ }^{28}$ Brian Loughnane, 'The Howard Government: Ten Years of Achievement for Australia',

<http://www.hudson.org/files/publications/BL_hudson_speech.pdf>.

${ }^{29}$ Nick Dyrenfurth, 'Battlers, Refugees and the Republic: John Howard's Language of Citizenship', Journal of Australian Studies, 84, 'Backburning', 2005. 